\title{
Study on concrete through its hardened state properties
}

\section{Estudo do concreto através de suas propriedades no estado endurecido}
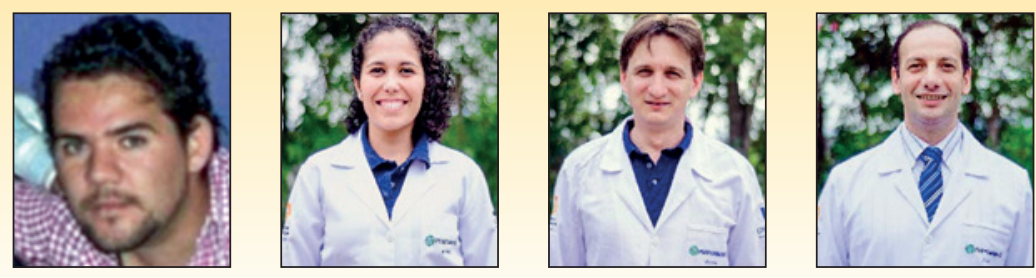

A. MONTELONGO alfredo.montelongo@ufrgs.br https://orcid.org/0000-0002-6568-5448

F. PACHECO b fernandapache@unisinos.br https://orcid.org/0000-0003-3455-491X

R. CHRIST b

rchrist@unisinos.br https://orcid.org/0000-0003-1367-8972

B. F. TUTIKIAN b

bftutikian@unisinos.br https://orcid.org/0000-0003-1319-0547

\begin{abstract}
The composition characteristics of concrete, such as water/cement ratio, cement consumption and compressive strength directly affect its handling performance and durability. Thus, the technical standards related to concrete structures recommend technical specification concerning different environmental aggressiveness classes. Therefore, this study followed an experimental method aiming to evaluate the relationship between the characteristics of four different concrete mixes produced in accordance to the specifications of the standards EN 1992-1 and EN 206 for quality of hardened state concrete and its behavior during accelerated tests of carbonation and salt spray. Analyzes of compressive strength, void index, total and capillary water absorption, specific gravity, electrical resistivity and ultrasonic wave propagation velocity were executed. For the statistical treatment, a Multivariate Analysis of Variance (MANOVA) was performed, which provided a simplified analysis of the durable potential of reinforced concrete structures by its characteristics. Results lead to two major groups of behavior, and statistical significant differences in deterioration tests between mixes 1 and 4 for the salt spray test and between mix 4 and the others for the carbonation test.
\end{abstract}

Keywords: concrete structures, durability, statistical analysis, technical specification.

\section{Resumo}

As propriedades dos concretos, como relação água/cimento, consumo de cimento e resistência à compressão afetam diretamente seu desempenho em uso e durabilidade. Desta forma, as normas técnicas de dimensionamento de estruturas de concreto armado indicam especificações em função das classes de agressividade ambiental. Neste artigo, através de uma metodologia experimental, foi avaliada a relação entre as características de quatro composições de concreto, elaboradas de acordo com as normas EN 1992-1 e EN 206, e sua relação com a qualidade do concreto no estado endurecido, nos ensaios de carbonatação e névoa salina. Foram empregadas análises de resistência à compressão, índice de vazios, absorção de água total e por capilaridade, massa específica, resistividade elétrica e velocidade de propagação de ondas ultrassônicas. Para o tratamento estatístico foi utilizada Análise multivariada da variância (MANOVA). Os resultados obtidos apontaram diferenças estatisticamente significantes nos ensaios de deterioração unicamente nos traços 1 e 4 para o ensaio de névoa salina e entre o traço 4 e os demais para o ensaio de carbonatação.

Palavras-chave: concreto, durabilidade, análise estatística, especificação técnica. 


\section{Introduction}

Concrete structures have been used worldwide for over 100 years due to their properties of resistance, versatility and load carrying capacity, in addition to mastery and vast knowledge of this technology [1-4] . Amid this period, professionals could learn the main characteristics of concrete and how these relate to durability and performance, and how to preserve the proper-ties. However, as occurs with structures knowledge, their composition has changed throughout time, given the constant evolution of materials and search for construction's impact minimization $[5,6]$

The everyday specification of concrete progresses, currently employing fine and microfine components such as pozzolans, superplasticizers, and improved adjustment of safety coefficients, originated from the advances in calculation procedures and structural design $[7,8,9]$.

This constant evolution requires technical standards that can instruct and tell professionals what characteristics must be followed in order to reach satisfactory behavior, considering that these criteria must concern the concrete's environmental aggressiveness class [10]. The documents that present such values are noteworthy, such as ACl-318, ABNT NBR 6118, EN 1992-1, EN 206, IS 456, AS 3600 and FIB 34 [11-17].

The aggressiveness classes deserve this attention when specifying the structures, as they point out what the dominant deterioration agents are and what damages could occur, given that the factors that favor deterioration are already known. Durable materials have been developed with the same aim of predicting behavior and deterioration of structures, hindering pathological manifestations, such as cracking [18], carbonation [19], and others, and increasing the lifespan of buildings, thus making them economically viable and satisfactory to users.

Coupled with the feasibility to perform accelerated deterioration tests, characterization tests have been developed, which may present characteristics that relate to the durability of multiple compositions of concrete and even predict the material's durable behavior $[1 ; 20]$.

Considering the scenario presented, this study aims to contribute evaluating relations between the characteristics stipulated for meeting concrete durability standards, specifically those presented by EN 1992-1 and EN 206:2013 [13-15], examining the durability potential of the mixes specified and how the durability of these materials can be predicted by performing hardened state tests.

\section{Concrete structures}

\subsection{Characteristics of concrete}

The analysis of concrete is split between properties of fresh and hardened states. The fresh state properties relate to flow, ability to cross obstacles and cohesion, whereas the hardened state counts with physical and mechanical characterizations of the material, among which stands out the compressive strength. Considering that the mixes differ with respect to their composition, many tests characterize and correlate their properties. Girskas et al. (2016), [21] Sardinha et al. (2016) [22] and Mohammadhosseini et al. (2017) [23] assessed hardened state tests and performed acceler- ated tests for predicting the durability of innovative materials. The main characteristics of concrete are as follows:

\section{Water/cement ratio}

The water/cement ratio indicates the concrete's durability. Its major utilization leads to more common occurrence of voids, which relates to a higher susceptibility to attack by deterioration agents of the structures [24].

- Compressive strength

Compressive strength is the concrete's most well-known characteristic, being the parameter that guides the design of structures. Nawy (2000) [25] points out that higher compressive strength relates to lower values of the w/c ratio, which, according to Neville (2015), [1] minimizes porosity and increases durability [26].

\section{- Cement consumption}

Cement is used for wrapping aggregates, making a single homogeneous material. Concretes with low cement consumption may be faulty concerning cohesion, presenting voids, lowering their lifespan and resistance to attack by deleterious agents [27].Wassermann, Katz and Bentur (2009) [28] pinpoint three reasons for which technical standards must present minimum values for cement consumption, being the workability of concretes, minimum content of fines and chemical protection for reinforcements.

\subsection{Accelerated tests for predicting the durabilty of concrete structures}

Accelerated deterioration tests seek to reproduce real phenomena in concretes, performed with higher concentration, in order to reduce the time required for analyzing these mechanisms. As reported by Helene (1997) [29], these tests consist of one of the lifespan prediction methods of ASTM E632 [30]. For tests performed on concretes, the accelerated tests of carbonation and salt spray exposure are noteworthy, as they simulate the main attacks buildings suffer.

Carbonation consists of carbon dioxide entering concrete structures. Its occurrence depends on countless factors, among which are the composition characteristics of the material, such as cement consumption, compressive strength, water/cement ratio and $\mathrm{CO}_{2}$ concentration. [31]. According to Duprat, Vu and Sellier (2014) [32], this phenomenon reduces concrete $\mathrm{pH}$ and, consequently, the passivation of reinforcements, which may lead to corrosion of the reinforcements. The accelerated carbonation test consists of putting samples in a closed environment with a controlled influx of $\mathrm{CO}_{2}$ and checking, throughout time, the attack front of this substance on the samples by using chemical indicators [31].

The salt spray attack affects structures near oceans, which are exposed to mists that contain chloride ions. [33]. Concerning accelerated tests, it is possible to speed up the ions influx by salt spray exposure in chamber [34]. This method has been known since the 1970's, although it is usually applied to metallic materials. [35]. It uses chemical indicators that measure the depth of the aggression by chlorides, in the same fashion as the accelerated carbonation test.

\section{Experimental procedure}

In order to evaluate the relation between the characteristics of four concrete mixes, specified in accordance to EN 1992-1 and 
Table 1

Concrete characteristics according to aggressively class

\begin{tabular}{cccc}
\hline $\begin{array}{c}\text { Concrete } \\
\text { treatments }\end{array}$ & $\begin{array}{c}\text { Compressive } \\
\text { strength } \\
\text { (MPa) }\end{array}$ & $\begin{array}{c}\text { Cement } \\
\text { consumption } \\
\left(\mathbf{k g} / \mathbf{m}^{3}\right)\end{array}$ & $\begin{array}{c}\text { Water/cement } \\
\text { ratio }\end{array}$ \\
\hline $\mathrm{T} 1$ & 25 & 260 & 0.65 \\
$\mathrm{~T} 2$ & 30 & 280 & 0.6 \\
$\mathrm{~T} 3$ & 35 & 320 & 0.55 \\
$\mathrm{~T} 4$ & 40 & 360 & 0.45 \\
\hline
\end{tabular}

EN 206 [13;14], and the behavior during the accelerated tests of carbonation and salt spray, this experiment relied on the following steps:

a) Summarization of the data obtained during the tests of Pacheco (2016) [36] for each concrete composition;

b) Descriptive analysis of the data and search for possible outliers;

c) Multivariate Analysis of Variance (MANOVA);

d) interpretation of the results.

\subsection{Data summarization}

Experiments were performed on four distinct concrete compositions (treatments). These compositions (T1, T2, T3 and T4) varied with respect to compressive strength, water/cement ratio and cement consumption, as recommended by [13;14] (Table 1), ranging from an aggressiveness class of lower deterioration potential to places of more severe aggression.

The variables evaluated were compressive strength (CS), void in$\operatorname{dex}(\mathrm{VI})$, specific gravity (SG), total water absorption (TWA), capillary water absorption (CWA), mercury intrusion porosimetry (MIP), ultrasonic wave transmission velocity (UWV), electrical resistivity (ER) and the accelerated tests of carbonation depth (CD) and salt spray (SS). The experimental procedure, its compositions and analysis performed are depicted in Figure 1.

\subsection{Description of samples and identification of outliers}

Each variable had its own descriptive values. Table 2 presents the response variables, their number of observations, mean values and standard deviation, besides maximum and minimum vales, and others.

Likely outliers were identified afterwards. The Boxplot tool was chosen for evaluating the existence of these dissonant data. For the capillary absorption variable, an anomalous point was found, occurring by the 84 days, on mix 2 . When organizing the values for electrical resistivity, ultrasonic wave propagation velocity and specific gravity, no exception points or outliers were found, whereas the analysis of void index displayed discrepancy on mixes 3 and 4 , with specific cement consumption of 320 and $360 \mathrm{~kg} / \mathrm{m}^{3}$.

\subsection{Multivariate analysis of variance (MANOVA)}

MANOVA was applied subsequently. MANOVA is a multivariate statistical technique which allows to evaluate if effects between groups, in an experimental setting, occur due to treatments or are merely at random [37;38]. The MANOVA structure relies on two types of variables: independent (treatments) and dependent (responses).

Afterwards, the statistical assumptions of Independence, Normality and Homoscedasticity were checked [37]. In order to assess if the data were normally distributed, the test of Shapiro-Wilk (1965) [39] was used. The theory of Shapiro-Wilk (1965) is based on two hypotheses: Ho the variable's data follow normal distribution and $\mathrm{H} 1$ the variable's data do not follow normal distribution. The significance, in this case, is $95 \%$. That way, when the p-value obtained from the sample is higher than $5 \%(p>0.05)$, Ho is not rejected, therefore the data are normally distributed [40].

Homoscedasticity was assessed through the test of Levene. Finally, the degree of correlation between dependent variables was obtained through the test of Barlett. The F-statistic was used for

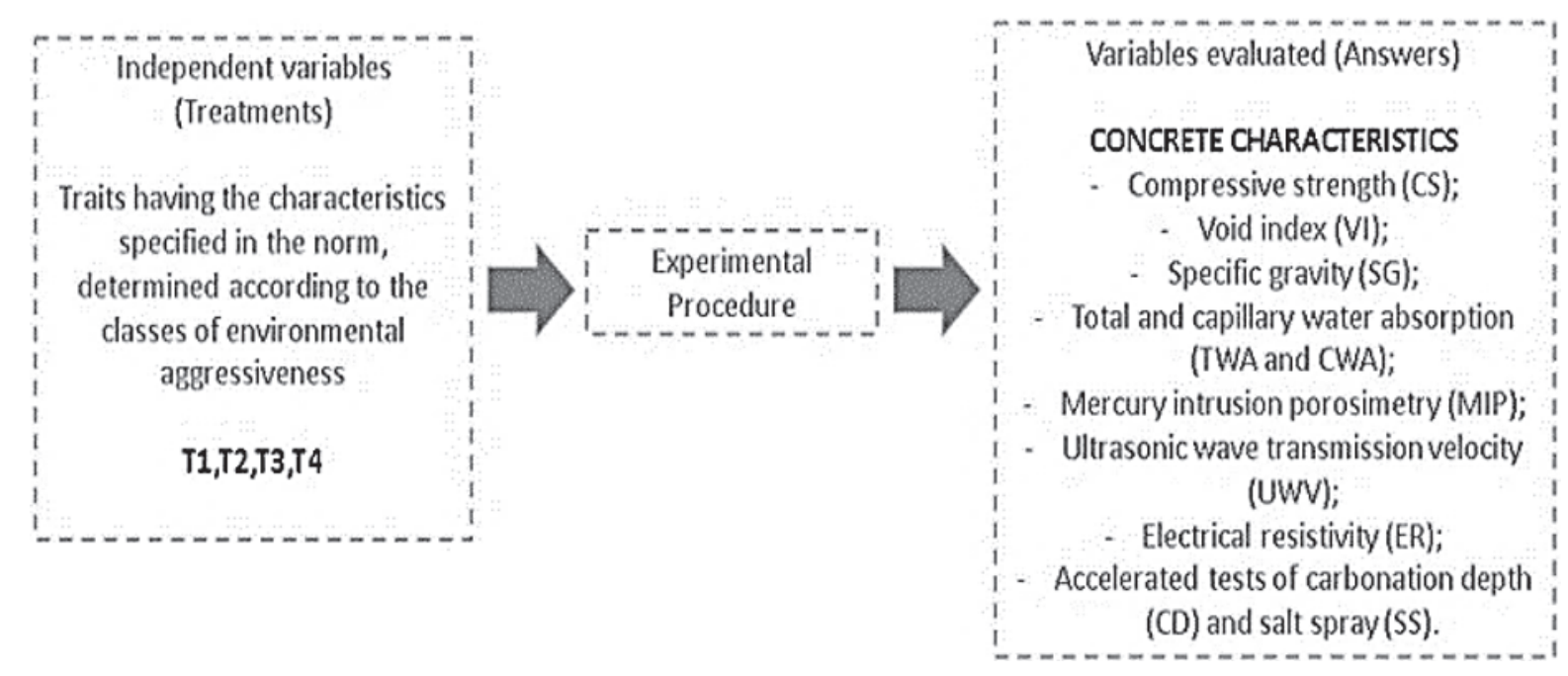

\section{Figure 1}

Experimental procedure 
Table 2

Sample description

\begin{tabular}{|c|c|c|c|c|c|c|c|c|}
\hline Variables & $\mathrm{N}^{\circ}$ of obs & Average & $\begin{array}{l}\text { Standard } \\
\text { deviation }\end{array}$ & Median & $\begin{array}{l}\text { Weighted } \\
\text { average }\end{array}$ & $\begin{array}{l}\text { Absolute } \\
\text { mean } \\
\text { deviation }\end{array}$ & $\begin{array}{l}\text { Minimum } \\
\text { value }\end{array}$ & $\begin{array}{l}\text { Maximum } \\
\text { value }\end{array}$ \\
\hline $\begin{array}{c}\text { Compressive } \\
\text { strenght }\end{array}$ & 60 & 37.11 & 12.14 & 34.3 & 35.5 & 9.56 & 21.5 & 67.8 \\
\hline Void ratio & 24 & 11.4 & 1.38 & 11.11 & 11.39 & 1.36 & 8.96 & 13.8 \\
\hline $\begin{array}{l}\text { specific } \\
\text { gravity }\end{array}$ & 24 & 2.54 & 0.04 & 2.54 & 2.54 & 0.04 & 2.44 & 2.6 \\
\hline $\begin{array}{l}\text { Total water } \\
\text { absorption }\end{array}$ & 24 & 5.08 & 0.68 & 4.91 & 5.07 & 0.69 & 3.91 & 6.22 \\
\hline $\begin{array}{l}\text { Capillary } \\
\text { water } \\
\text { absorption }\end{array}$ & 24 & 1.67 & 2.15 & 1.26 & 1.27 & 0.16 & 0.56 & 11.68 \\
\hline $\begin{array}{c}\text { Mercury } \\
\text { intrusion } \\
\text { porosimetry }\end{array}$ & 4 & 0.06 & 0.04 & 0.05 & 0.06 & 0.04 & 0.01 & 0.11 \\
\hline $\begin{array}{l}\text { Ultrasonic } \\
\text { wave } \\
\text { transmission } \\
\text { velocity }\end{array}$ & 36 & 4675.8 & 130.65 & 4641.8 & 4669.77 & 138.61 & 4484.65 & 4915.65 \\
\hline $\begin{array}{l}\text { Electrical } \\
\text { resistivity }\end{array}$ & 72 & 38.43 & 19.4 & 34.75 & 35.67 & 17.79 & 15.5 & 89.4 \\
\hline $\begin{array}{c}\text { Carbonation } \\
\text { depth }\end{array}$ & 16 & 6.7 & 5.29 & 4.58 & 6.59 & 4.68 & 0 & 14.9 \\
\hline $\begin{array}{l}\text { Salt spray } \\
\text { attack depth }\end{array}$ & 8 & 9.83 & 4.38 & 10.75 & 9.83 & 4.67 & 3 & 15.2 \\
\hline
\end{tabular}

interpreting the data from MANOVA verification. The higher this value is, the higher the difference between groups is. [37].

\subsection{Analysis of variance (ANOVA) and Pos-hoc test}

After MANOVA, a test of ANOVA was performed. Lastly, a post-hoc analysis for the statistically significant ANOVA variables was carried out. The main difference between the post-hoc analysis and ANOVA is that ANOVA indicates if there is significant difference between groups, while the post-hoc analysis measures between what groups this difference can be found [41-42].

\section{Results}

\subsection{Independence and normality}

The assumption of independence was satisfied due to the use of different samples. Normality, as presented in Table 3, was confirmed for all variables except electrical resistivity regarding levels 240 (T1), 280 (T2) and 360 (T4) ( $p>0.05)$. However, given the relevance of this test and its non-destructive nature for analyzing structures, these data were kept. The tests of mercury intrusion porosimetry and salt spray had few repetitions, given their complexity, and their normality could not be tested, since at least 3 variables per treatment are required for the normality analysis. The porosimetry test was performed only once for each mix, and the salt spray test, in varied ages.

\subsection{Homoscedasticity}

Table 4 presents the Levene test for equality of variances (homoscedasticity). As occurs in the normality test, when $p<0.05$, it is said that there is no variance equality [40]. Therefore, the variables compressive strength (CS), void index (VI), electrical resistivity (ER) and salt spray (SS) displayed values below $(p<0.05)$, indicating that the variances are not equal. Nevertheless, as the aim of this study was to validate all analyzes, these variables were not discarded.

\subsection{Visual inspection}

In order to set up a first description of the treatments' behavior, the means of the response variables were plotted in a single diagram.

Table 3

Samples' normality test

\begin{tabular}{ccccccccc}
\hline Traço & CS & VI & SG & TWA & CWA & UWV & ER & CD \\
\hline T1 & 0.169 & 0.125 & 0.371 & 0.124 & 0.389 & 0.732 & 0.008 & 0.529067 \\
T2 & 0.093 & 0.208 & 0.739 & 0.235 & 0.126 & 0.478 & 0.007 & 0.781314 \\
T3 & 0.878 & 0.484 & 0.452 & 0.157 & 0.507 & 0.987 & 0.065 & 0.387294 \\
T4 & 0.017 & 0.694 & 0.158 & 0.821 & 0.433 & 0.214 & 0.011 & 0.236685 \\
\hline
\end{tabular}


Table 4

Leven's test (homoscedasticity)

\begin{tabular}{ccccc} 
& F & Df1 & Df2 & Sig \\
\hline CS & 0.00051 & 3 & 56 & 0.00051 \\
VI & 0.001898 & 3 & 17 & 0.001898 \\
SG & 0.1763 & 3 & 20 & 0.1763 \\
TWS & 0.04233 & 3 & 20 & .04233 \\
CWA & 0.2272 & 3 & 19 & 0.2272 \\
MIP & NA & 3 & NA & NA \\
UWV & 0.2175 & 3 & 32 & 0.2175 \\
ER & 0.007029 & 3 & 68 & 0.007029 \\
CD & 2.3661 & 3 & 12 & 0.1222 \\
SS & $1.81 e+30$ & 3 & 3 & $2.20 E-16$ \\
\hline
\end{tabular}

The values were standardized (scaled) so that it would be possible to assess their macro behavior within a same unit. Figure 2 displays the plotting of the variables after being standardized.

As noticed, the variables portrayed two groups of similar behavior, being the first with the variables compressive strength (CS), specific gravity (SG), ultrasonic wave propagation velocity (UWV), electrical resistivity (ER), and the second with total water absorption (TWA), void index (VI), capillary water absorption (CWA), mercury intrusion porosimetry (MIP), carbonation depth (CD) and salt spray (SS). This binary division typifies the variables' macro behavior, which further leads to the verification of between what points of analysis differences can be found. This macro behavior was expected, as some independent variables are related, due to physical characteristics of concrete. For instance, it is known that concretes with higher void index (group 2) will present higher total and capillary water absorption (group 2), whereas such variables are inversely proportional to compressive strength (group 1). It was also noted, through the diagram plot, that the similarities are higher among the variables of group 1 than group 2 .

As noticed, the variables portrayed two groups of similar behavior, being the first with the variables compressive strength (CS), specific gravity (SG), ultrasonic wave propagation velocity (UWV), electrical resistivity (ER), and the second with total water absorption (TWA), void index (VI), capillary water absorption (CWA), mercury intrusion porosimetry (MIP), carbonation depth (CD) and salt spray (SS). This binary division typifies the variables' macro behavior, which further leads to the verification of between what points of analysis differences can be found. This macro behavior was expected, as some independent variables are related, due to physical characteristics of concrete. For instance, it is known that concretes with higher void index (group 2) will present higher total and capillary water absorption (group 2), whereas such variables are inversely proportional to compressive strength (group 1). It was also noted, through the diagram plot, that the similarities are higher among the variables of group 1 than group 2 .

\subsection{MANOVA}

Based on the visual inspection and the theoretical knowledge on

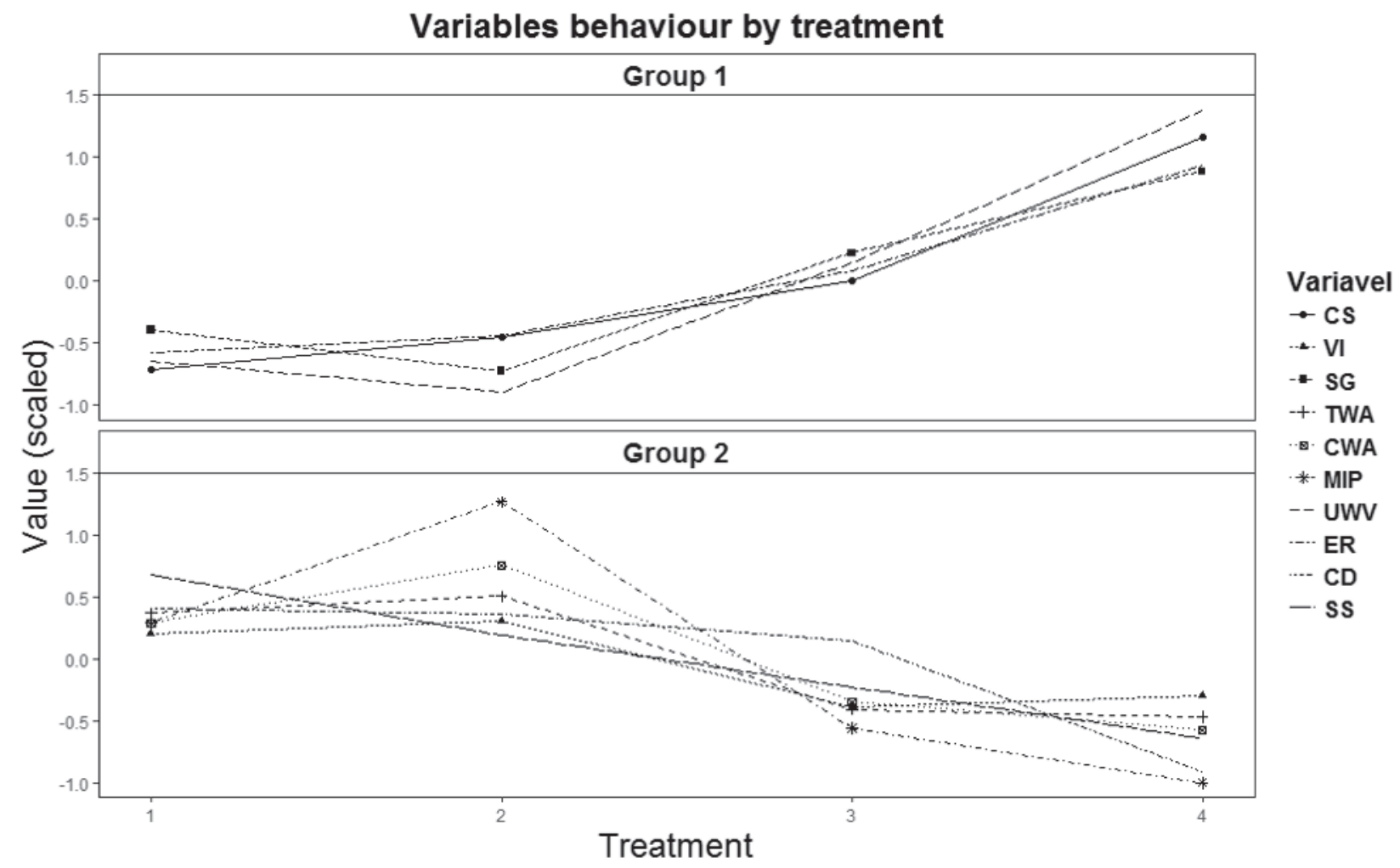

Figure 2

Graphic of variables after scaling 
Table 5

Leven's test (homoscedasticity)

\begin{tabular}{ccc} 
& Group 1 & Group 2 \\
\cline { 2 - 3 } & 54.227 & 30.295 \\
Bartlett's K-squared & 15 & 19 \\
Df & $2.407 \mathrm{e}-06$ & 0.04816 \\
\hline
\end{tabular}

how the variables tend to relate, each group received MANOVA treatment to better understand the phenomenon

\subsubsection{Correlation between dependent variables}

Before applying the MANOVA technique, one should test for correlation between dependent variables [37]. As referred in Table 5, each block presents statistical significance $(p<0.05)$, implying an acceptable degree of correlation between dependent variables. Analyzing the behavior between both groups, it was noted that Block 1 presented a p-value much smaller than Block 2, that is, the variables behaved similarly amid distinct treatments. In Block 2 , there is discrepancy between mercury intrusion porosimetry and the other variables, what may have caused the increased deviation between samples.

As depicted in Table 6, the test is divided in two groups due to the behavior discussed previously. Group 1 presents significance $(p<0.05)$ for all tests. For group 2, only Roy's test was significant $(p<0.05)$.

Next, the ANOVA test was performed to check variability between treatments, for each variable. Its results can be found in Table 7.

In accordance to what has been presented, the variables of com-
Table 6

MANOVA Results

\begin{tabular}{ccccc}
\hline \multicolumn{5}{c}{ Group 1 } \\
\hline Test & Value & $\mathbf{F}$ & df & Sig. \\
\hline Pillais & 2.1305 & 4.0425 & 3 & 0.001779 \\
Wilks & 0.000629 & 17.143 & 3 & $3.515 \mathrm{E}-06$ \\
Hotelling- & 148.86 & 45.484 & 3 & $1.339 \mathrm{E}-07$ \\
Lawley & 141.22 & 247.14 & 3 & $1.305 \mathrm{E}-07$ \\
Roy & 0.017 & 0.694 & 0.158 & 0.821 \\
T4 & \multicolumn{5}{c}{ Group 2 } \\
\hline \multicolumn{5}{c}{$\mathbf{F}$} \\
\hline Test & Value & df & Sig. \\
\hline Pillais & 1.139 & 1.2153 & 9 & 0.3448 \\
Wilks & 0.12025 & 1.5243 & 9 & 0.261 \\
Hotelling- & 5.2467 & 1.5546 & 3 & 0.2727 \\
Lawley & 4.8294 & 9.6588 & 3 & 0.01031 \\
Roy & 0.017 & 0.694 & 0.158 & 0.821 \\
T4 & \multicolumn{3}{c}{}
\end{tabular}

pressive strength, specific gravity, capillary water absorption, ultrasonic wave transmission velocity and electrical resistivity have significant differences between treatments, or type of mix. The other samples displayed $p$-value greater than 0.05 , so they were not influenced by the treatments. Since ANOVA only assesses if there is difference between treatments and results, a post-hoc analysis was performed, with the Tukey Test, checking between which concrete compositions there were significant differences for the accelerated deterioration tests. Table 8 presents the analysis regarding the accelerated carbonation test.

\section{Table 7}

ANOVA Results

\begin{tabular}{|c|c|c|c|c|c|c|}
\hline \multicolumn{2}{|c|}{ Variables and results } & df & SS & Mean of square & $\mathbf{F}$ & $P$ value \\
\hline \multirow{2}{*}{$\begin{array}{l}\text { Compressive } \\
\text { strength }\end{array}$} & Treatment & 1 & 4097 & 4097 & \multirow{2}{*}{51.63} & \multirow{2}{*}{$1.43 \times 10_{-9}$} \\
\hline & Residuals & 58 & 4602 & 79 & & \\
\hline \multirow{2}{*}{ Void index } & Treatment & 1 & 1.973 & 1.973 & \multirow{2}{*}{1.201} & \multirow{2}{*}{0.287} \\
\hline & Residuals & 19 & 31.196 & 1.642 & & \\
\hline \multirow{2}{*}{ Specific gravity } & Treatment & 1 & 0.011 & 0.011 & \multirow{2}{*}{9.427} & \multirow{2}{*}{0.0056} \\
\hline & Residuals & 22 & 0.0262 & 0.001 & & \\
\hline \multirow{2}{*}{$\begin{array}{l}\text { Total water } \\
\text { absorption }\end{array}$} & Treatment & 1 & 1.612 & 1.612 & \multirow{2}{*}{3.963} & \multirow{2}{*}{0.0591} \\
\hline & Residuals & 22 & 8.951 & 0.406 & & \\
\hline \multirow{2}{*}{$\begin{array}{c}\text { Capillary water } \\
\text { absorption }\end{array}$} & Treatment & 1 & 0.301 & 0.301 & \multirow{2}{*}{4.474} & \multirow{2}{*}{0.0465} \\
\hline & Residuals & 21 & 1.414 & 0.067 & & \\
\hline \multirow{2}{*}{$\begin{array}{l}\text { Mercury intrusion } \\
\text { porosimetry }\end{array}$} & Treatment & 1 & 0.003 & 0.003 & \multirow{2}{*}{2.354} & \multirow{2}{*}{0.265} \\
\hline & Residuals & 22 & 0.003 & 0.001 & & \\
\hline \multirow{2}{*}{$\begin{array}{l}\text { Ultrasonic wave } \\
\text { transmission } \\
\text { velocity }\end{array}$} & Treatment & 1 & 391621 & 391621 & \multirow[b]{2}{*}{64.68} & \multirow{2}{*}{$2.25 \times 10^{-9}$} \\
\hline & Residuals & 34 & 205856 & 6055 & & \\
\hline \multirow{2}{*}{$\begin{array}{l}\text { Electrical } \\
\text { resistivity }\end{array}$} & Treatment & 1 & 8650 & 8650 & \multirow{2}{*}{33.49} & \multirow{2}{*}{$1.86 \times 10^{-7}$} \\
\hline & Residuals & 70 & 18083 & 258 & & \\
\hline \multirow{2}{*}{$\begin{array}{l}\text { Carbonation } \\
\text { depth }\end{array}$} & Treatment & 1 & 96.7 & 96.69 & \multirow{2}{*}{4.2} & \multirow{2}{*}{0.0596} \\
\hline & Residuals & 14 & 322.3 & 23.02 & & \\
\hline \multirow{2}{*}{ Salt spray } & Treatment & 1 & 36.48 & 36.48 & \multirow{2}{*}{2.236} & \multirow{2}{*}{0.185} \\
\hline & Residuals & 6 & 97.87 & 16.31 & & \\
\hline
\end{tabular}


Table 8

Tukey test - carbonation depth

\begin{tabular}{cccc}
\hline $\begin{array}{c}\text { Treatments } \\
\text { compared }\end{array}$ & $\mathrm{p}$ value & $\begin{array}{c}\text { Treatments } \\
\text { compared }\end{array}$ & $\mathrm{p}$ value \\
\hline T2-T1 & 0.9983 & T3-T2 & 0.8805 \\
T3-T1 & 0.8054 & T4-T2 & 0.0071 \\
T4-T1 & 0.0056 & T4-T3 & 0.0204 \\
\hline
\end{tabular}

It was found that only between mix 4 and the others there were significant differences. When comparing other mixes, no significant differences were found. Analyzing the mixes specified in this research, it was noted that the difference in water/cement ratio between this mix and the others was 0.10 at least, which suggests expressive changes to the presence of voids in the material, influencing the analysis. The difference between other traces was only 0.05 , which may not have provoked expressive changes in their composition. Table 9 presents the analysis concerning the chloride ions penetration front.

Considering the contents of Table 9, a significant difference was found between mixes T1 and T4, showing that changes in concrete composition do not have a significant impact on its durability with regards to chloride ions penetration front. Furthermore, the behavior suggests phenomena that may have affected only mix 4 , which may have had its pores clogged and the attack stagnated.

\section{Conclusion}

This study aimed to assess how concrete characteristics relate to each other and what impact they have on the accelerated deterioration tests of salt spray and carbonation. By the means of multivariate analysis of variance, two major groups of behavior were found: with increasing and decreasing variation concerning treatments. The increasing one displayed more similarities between variables for different treatments, while the decreasing one has more variance within a same block. The ANOVA pointed out that some of the tests were influenced by the type of mix, whereas the accelerated tests were seemingly not affected by the treatments. Tukey's test for the carbonation test showed that only mix 4 resulted in significant differences. For the salt spray test, the difference was significant only when comparing mixes $\mathrm{T} 1$ and $\mathrm{T} 4$, that is, the ultimate mixes with respect to concrete specification.

\section{References}

[1] NEVILLE, A. M. (2015) Propriedades do Concreto. Porto Alegre, Rio Grande do Sul: Bookman.

[2] ROSTAMI, M; BEHFARNIA, K. (2017) The effect of silica fume on durability of alkali activated slag concrete. Construction and building materials Vol (134), 262-268, doi: 1016/j.conbuildmat.2016.12.072.

[3] SCHAEFFER, R.E. (1992)- Reinforced Concrete: Preliminary Design for Architects and Builders, Michigan, Michigan: McGraw-Hill.

[4] PACHECO, F. et al . SEM and 3D microtomography application to investigate the distribution of fibers in advanced cementitious composites. Rev. IBRACON Estrut.
Table 9

Tukey test- salt spray

\begin{tabular}{cccc}
\hline $\begin{array}{c}\text { Treatments } \\
\text { compared }\end{array}$ & $\mathrm{p}$ value & $\begin{array}{c}\text { Treatments } \\
\text { compared }\end{array}$ & $\mathrm{p}$ value \\
\hline T2-T1 & 0.3921 & $\mathrm{~T} 3-\mathrm{T} 2$ & 0.4856 \\
$\mathrm{~T} 3-\mathrm{T} 1$ & 0.1134 & $\mathrm{~T}-\mathrm{T} 2$ & 0.1450 \\
$\mathrm{~T} 4-\mathrm{T} 1$ & 0.0452 & $\mathrm{~T} 4-\mathrm{T} 3$ & 0.5208 \\
\hline
\end{tabular}

Mater., São Paulo , v. 9, n. 6, p. 824-841, 2016, doi: 10.1590/s1983-41952016000600002

[5] MEHTA, P.K. (2002) Greening of the concrete industry for sustainable development. Concrete international, 23-28.

[6] DI LUZIO, G.; FERRARA, L.; KRELANI, V. Numerical modeling of mechanical regain due to self-healing in cement based composites. Cement and Concrete Composites, v. 86 , p. 190-205, 2018, doi: 10.1016/j.cemconcomp.2017.11.006

[7] DYER, T. (2014). Concrete Durability. London, New York: Boca Raton- CRC Press.

[8] HASSOUN, M. N; AL-MANASEER, A. (2015) Structural Concrete: Theory and Design. Hoboken, New Jersey: Wiley.

[9] TUTIKIAN, B. F; ISAIA, G. C; HELENE, P (2011). Concreto de Alto e Ultra-Alto Desempenho. In: ISAIA, Geraldo Cechella. Concreto: Ciência e Tecnologia. São Paulo, IBRACON, Cap. 36, 1283-1326.

[10] PACHECO, FERNANDA; DE SOUZA, RODRIGO PÉRICO ; CHRIST, ROBERTO ; ROCHA, CLARISSA ARGENTI ; SILVA, LUIS ; TUTIKIAN, BERNARDO . Determination of volume and distribution of pores of concretes according to different exposure classes through 3D microtomography and mercury intrusion porosimetry. Structural Concrete, v. 2018, p. 1-9, 2018, doi: 10.1002/ suco. 201800075

[11] American concrete Institute- $\mathrm{ACl} 318$, Building Code Requirements for Structural Concrete (ACI 318-05)

[12] ASSOCIAÇÃO BRASILEIRA DE NORMAS TÉCNICAS. NBR 6118: Projeto de estruturas de concreto - Procedimento. Rio de Janeiro: Associação Brasileira de Normas Técnicas, 2014. 238 p.

[13] EUROPEAN COMMITTEE FOR STANDARDIZATION. EN 1990: Eurocode - Basis of structural design. Brussels: European Committee For Standardization, 2000.

[14] EUROPEAN COMMITTEE FOR STANDARDIZATION. EN 206-1: Concrete - Specification, performance, production and conformity. Brussels: European Committee For Standardization, 2013

[15] BUREAU OF INDIAN STANDARDS. IS 456: Plain and Reinforced Concrete - Code of Practice. New Delhi, 2000.

[16] AUSTRALIAN STANDARD. AS 3600: Concrete structures. Sydney: Standards Australia Limited, 2009.

[17] FIB - International Federation for Structural Concrete Bulletin 34, Model code for service life design, 2010.

[18] HAVLASEK P., JIRASEK M. (2016) Multiscale modeling of drying shrinkage and creep of concrete. Cement and concrete research vol (85),55-74. doi: 10.1016/j.cemconres.2016.04.001 
[19] POSSAN, E. (2010) Modelagem da carbonatação e previsão de vida útil de estruturas de concreto em ambiente urbano. 2010. 265 f. Dissertação (Mestrado) - Programa de Pós-graduação em Engenharia Civil, Escola de Engenharia, Universidade Federal do Rio Grande do Sul, Porto Alegre.

[20] RABEHI, M; MEZGHICHE, B; GUETTALA, S. (2013) Correlation between initial absorption of the cover concrete, the compressive strength and carbonation depth. Construction and Building Materials, v (45), 123-129, doi:1016/j.conbuildmat.2013.03.074

[21] GIRSKAS, G; SKRIPKUNAS, G; SAHMENKO, G; KORJAKINS, A. (2016) Durability of concrete containing synthetic zeolite from aluminum fluoride production waste as a supplementary cementitious material. Construction and building materials, vol (117), 99-106, doi: 1016/j.conbuildmat.2016.04.155

[22] SARDINHA, M; BRITO, J; RODRIGUES, R. (2016) Durability properties ofstructural concrete containing very fine aggregates of marble sludge. Construction and building materials, vol (119), 45-52, doi: 1016/j.conbuildmat.2016.05.071.

[23] MOHAMMADHOSSEINI, H; Yatim, J.M; SAM, A.R.M; AWAL, A.S.M.A (2017). Durability performance of green concrete composites containing waste carpet fibers and palm oil fuel ash. Journal of cleaner production, Vol (164), 448-458, doi: 1016/j.jclepro.2016.12.151

[24] OZTURK, A. U; ONAL, O (2013) Identification of water/ cement ratio of cement pastes, basing on the microstructure image analysis data and using artificial neural network. KSCE Journal of Civil Engineering, v(17), n. 4, 76376, doi: 1007/s12205-013-0156-9

[25] NAWY, E. (2000) Fundamentals of High-Performance Con-crete. New York, Wiley.

[26] BASHEER, L; KROPP, J; CLELAND, D J (2001). Assessment of the durability of concrete from its permeation properties: a review. Construction and building materials, v(15), n. 2, 93-103, doi: 1016/S0950-0618(00)00058-1

[27] SALAS, D. A. et al. Environmental impacts, life cycle assessment and potential improvement measures for cement production: A literature review. Journal of Cleaner Production, v. 113, p. 114-122, 2016.

[28] WASSERMANN, R.; KATZ, A.; BENTUR, A (2009). Minimum cement content requirements: a must or a myth? Materials and Structures, v(42), 973-982, doi: 10.1617/ s11527-008-9436-0

[29] HELENE, Paulo. (1997) Vida Útil das Estruturas de Concreto. In: Congresso Ibero Americano De Patologia Das Construções (CONPAT), Porto Alegre: Conpat.

[30] AMERICAN SOCIETY FOR TESTING AND MATERIALS ASTM E632-82: Standard Practice for Developing Accelerated Tests to Aid Prediction of the Service Life of Building Components and Materials. West Conshohocken: ASTM International, 1996. $6 \mathrm{p}$

[31] PAULETTI, Cristiane et al. (2009) Degradação do concreto por carbonatação: execução do ensaio. Revista Concreto e Construções, (v. 53), 35-42, ISSN 1809-7197
[32] DUPRAT, F.; VU, N. T.; SELLIER. A (2014) Accelerated carbonation tests for the probabilistic prediction of the durability of concrete structures. Construction and Building Materials vol (66), 597-605, doi: 1016/j.conbuildmat.2014.05.103

[33] MORAES FILHO. J.E (2013). Avaliação da resistência do concreto ao meio ambiente em estrutura de concreto do Porto do Recife: estudo de caso, 2013, 133f. Dissertação (Mestrado)- Curso de Programa de pós-graduação em engenharia civil, Escola Politécnica, Universidade de Pernambuco, Recife.

[34] BASSOUNI, M.T; RAHMAN, MM (2016). Response to concrete to accelerated physical salt attack exposure. Cement and concrete research. Vol (79), 395-408, doi: 1016/j.cemconres.2015.02.006.

[35] SOUZA, D.O. et al. (2012) Investigação da corrosividade do ensaio de névoa salina segundo norma ISO 9227. In: Encontro e exposição brasileira de tratamento de superficie/III interfinish, EBRATS 2012- São Paulo, 360 - 367.

[36] PACHECO, F. (2016) Investigação da relação entre os parâmetros de projeto das estruturas de concreto armado visando à durabilidade. São Leopoldo, 2016, 195p. (Mestrado em Engenharia Civil) - Pós-graduação Unisinos, São Leopoldo.

[37] HAIR JR, J; BLACK, W.C; BABIN, B.J; ANDERSON, R.E (2014) Multivariate data analysis. Pearson new international edition. Pearson education limited.

[38] WARNE, (2014). A Primer on Multivariate Analysis of Variance (MANOVA) for Behavioral Scientists. Practical Assessment, Research \& Evaluation, 19(17), 1-10, ISSN 1531-7714.

[39] LOPES, M. M., BRANCO, V.T.F.C.B, \& SOARES, J. B. (2013). Utilização dos testes estatísticos de KolmogorovSmirnov e Shapiro-Wilk para verificação da 56 normalidade para materiais de pavimentação. TRANSPORTES, 21(1), 59-66, doi:10.4237/transportes.v21i1.566

[40] MARÔCO, João (2003). Análise Estatística com o SPSS Statistics. Lisboa: Edições Sílabo.

[41] Tukey, J. W. (1960). A survey of sampling from contaminated distributions. In Olkin, I. (Ed.), Contributions to probability and statistics: Essays in honor of Harold Hotelling (pp. 448-485). Stanford, CA: Stanford University Press

[42] CONAGIN, A; BARBIN, D; DEMETRIO, C.G.B (2008). Modifications for the tukey test procedure and evaluation of the power and efficiency of multiple comparison procedures. Sci. Agric. v.65, 428-432, doi: 10.1590/S010390162008000400016. 